\title{
Analysis of Natural Vulnerability of Groundwater Intakes to Migration of Surface Pollutants Based on a Selected Part of the Dunajec River Basin
}

\author{
Ewa Wysowska ${ }^{1 *}$, Alicja Kicińska², Grzegorz Nikiel ${ }^{3}$ \\ ${ }^{1}$ Sądeckie Wodociągi Sp. z o.o., Nowy Sącz / AGH University of Science and Technology, Faculty of Geology, \\ Geophysics and Environmental Protection, Department of Environmental Protection, Krakow, Poland \\ ${ }^{2}$ AGH University of Science and Technology, Faculty of Geology, Geophysics and Environmental Protection, \\ Department of Environmental Protection, Krakow, Poland \\ ${ }^{3}$ Geobios Sp. z o.o., Częstochowa, Poland
}

Received: 27 May 2019

Accepted: 31 July 2019

\begin{abstract}
The article presents the evaluation of the vulnerability of groundwater to pollution with the use of the DRASTIC method and by determining the vertical filtering time through the aeration zone on the example of the groundwater intake in the Dunajec River valley. The study area was further divided into 3 catchment areas, equivalent to the 3 terraces of the river valley (characterized by different hydrodynamic properties). With the help of the DRASTIC method one made valuable analysis of individual environmental characteristics in terms of their protective functions for the analyzed waterbearing system and estimated vertical migration time, which served for the assessment of the level of exposing waters to potential conservative pollutants. The performed analyses demonstrated medium vulnerability in the case of cut-in-fill terrace and high vulnerability in the case of non-flood terrace and flood plain terrace. The results were used to develop a map representing spatial distribution of groundwater pollution vulnerability. There exists a correlation between the applied methods of vulnerability evaluation in a porous hydrogeological medium - the calculation of vertical infiltration time and the DRASTIC index. Conducted analyses give the possibility of implementation of obtained results for planning works and their use in putting into action appropriate methods of risk manipulation.
\end{abstract}

Keywords: natural vulnerability of groundwater, environmental risk, pollutant, DRASTIC

\section{Introduction}

Human presence and activity affect the environment, including groundwater, in a number of

*e-mail: ewa.wysowska@swns.pl

ways $[1,2]$. Therefore, actions aimed toward minimising negative anthropogenic impact are currently part of environmental risk management activities [3, 4].

The evaluation of sensitivity to environmental factors that determine the level of the potential risk is called vulnerability to pollution. The term natural (intrinsic) vulnerability of groundwater is defined as a natural property of the water system determining the 


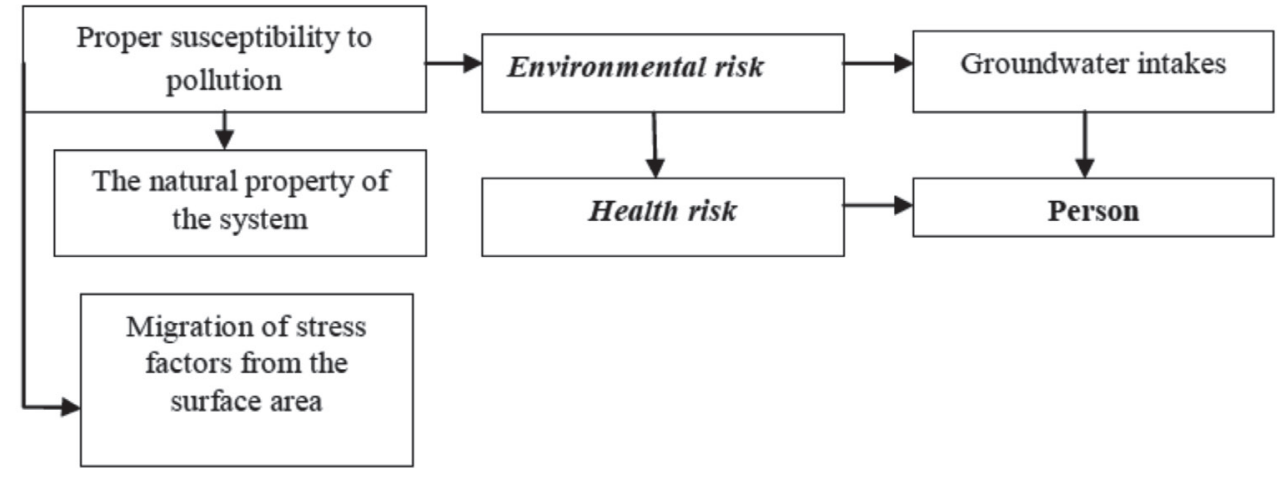

Fig. 1. Scheme of relations between health and environmental risk.

risk of pollutant migration. The value of this parameter depends solely on environmental factors and is not affected by the type of pollutant to which the specific vulnerability of groundwater applies [5]. The antonym of vulnerability is pollution resistance. It defines the ability of a hydrogeological system to protect itself against potential contamination and to delay the migration of pollutants [5], which in turn leads to environmental risk reduction.

Since environmental risk is undoubtedly connected with health risk, vulnerability to stress factors in the context of groundwater intake is an important issue in

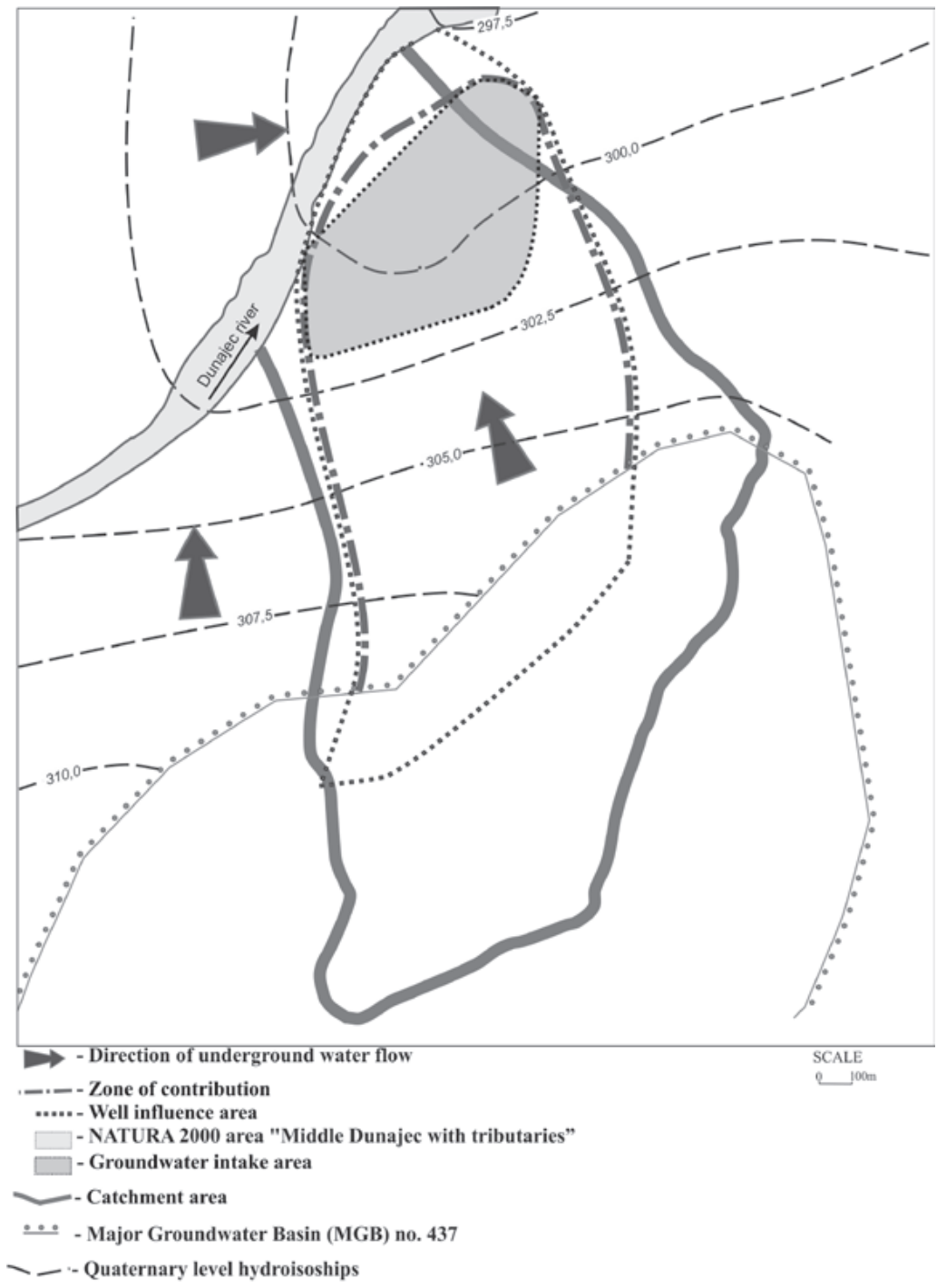

Fig. 2. Hydrogeological map of the area of research [7]. 
the process of supplying safe and clean water (Fig. 1).

This paper presents the results of an evaluation of natural vulnerability of groundwater with the use of the DRASTIC method, determining the time of vertical movement of water into the soil medium investigated.

\section{Materials and Methods}

The study covered the first Quaternary aquifer situated in the right part of the Dunajec River basin in the Beskid Sądecki mountain range [6]. This area includes a multiple well groundwater intake and its water supply area, as presented in Fig. 2. The water intake analysed comprises 16 deep wells and 3 units of infiltration basins [7]. It uses ground water taken directly from the aquifer or surface water from the river supplied through a system of infiltration basins artificially feeding the aquifer [8].

According to regional divisions proposed by Paczyński and Sadurski [9], the Dunajec River Basin is part of the Upper Vistula region, Outer Carpathians sub-region. The total surface of the river basin is $6804.1 \mathrm{~km}^{2}$, with $4851.6 \mathrm{~km}^{2}$ situated within Polish territory. The analysed section of the river basin covers the area where wells are located, and the water intake zone of influence, with a total surface of about 26 ha; it was delimited using the AEM (analytic element method) mathematical modelling of water flow to the intake in natural conditions [10]. The Dunajec River both drains and feeds groundwater, which remains in hydraulic contact with surface water. The groundwater intake studied is located in the first (flood plain) terrace, reaching about $3 \mathrm{~m}$ above the river's mean water level. The existing geomorphological conditions significantly influence the directions of lateral flow of groundwater and the surface flow towards the river valley following the ground inclination. The average annual precipitation in the area analysed is about 700-800 $\mathrm{mm}$.

From the geological perspective, the area belongs to the Western Outer Carpathian Mountains subregion in the Bystrzyca sub-unit, which is a part of the Magura Nappe. The Quaternary formations are mainly comprised of material from river outwash. Terraces are built of gravel, pebbles, and sand, with a small clay content. The thickness of the Quaternary formations within the discussed groundwater intake is about $10 \mathrm{~m} \mathrm{[7].} \mathrm{The} \mathrm{average} \mathrm{depth} \mathrm{of} \mathrm{wells} \mathrm{does} \mathrm{not} \mathrm{exceed}$
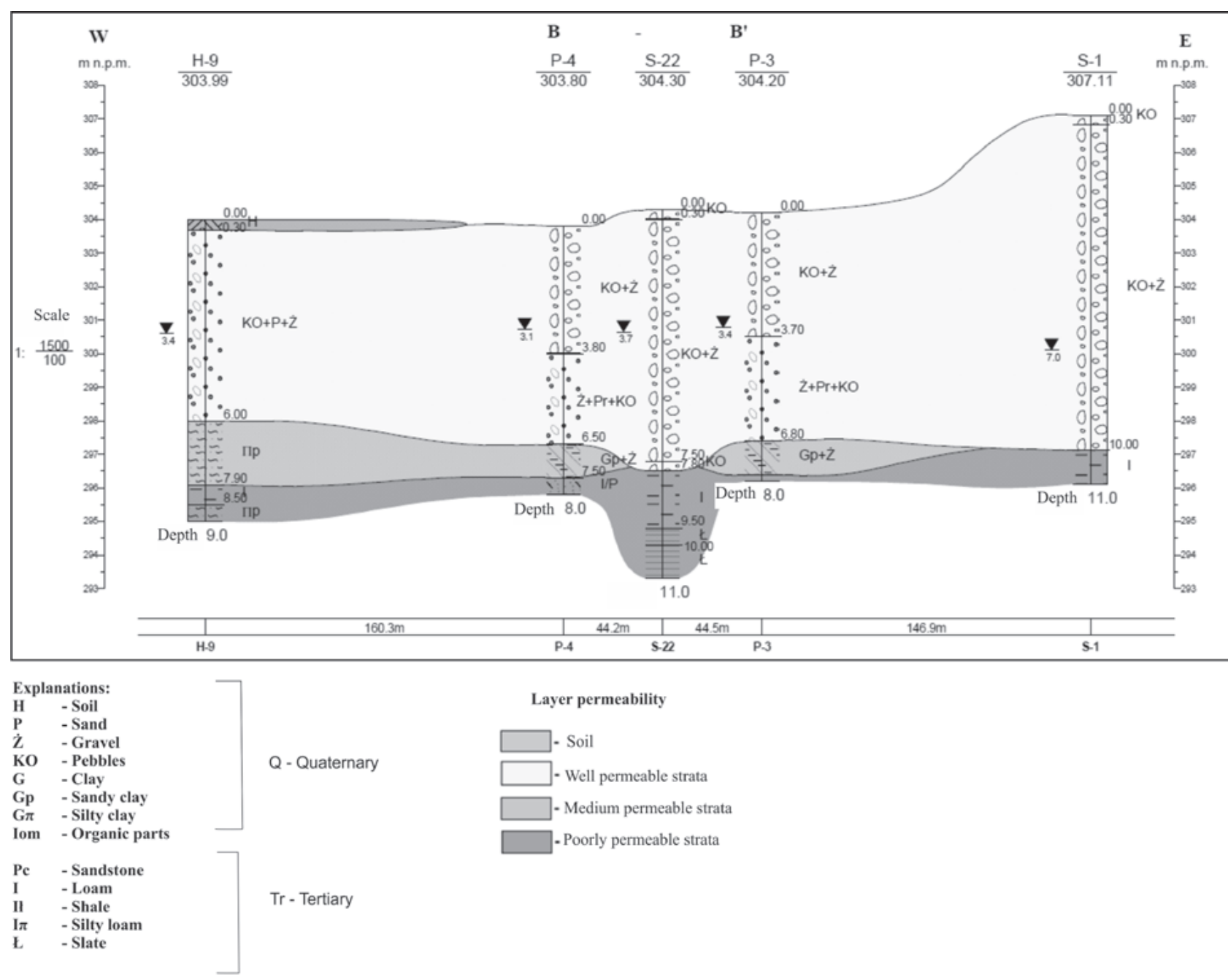

Fig. 3. Geological cross-section of chosen well holes [7]. 
10-11 m. The Quaternary formations are mostly comprised of highly permeable materials (silty sand with gravel, gravel with pebbles). The thill of Quaternary formations contains interbeddings of lowpermeability rock, mostly clays, while below there are other low-permeability materials (silts) belonging to an older bedrock. The geological structure creates complex conditions for groundwater protection. Fig. 3 presents the geological profile of selected wells of the water intake discussed.

From the hydrological perspective, the study area is located in the porous Major Groundwater Basin (MGB) No. 437 (Dunajec River Valley, Nowy Sącz) [11]. Its water resources were formed mostly owing to Quaternary formations as the sediments of the Carpathian flysch have a relatively low waterbearing capacity [9]. The Quaternary usable aquifer is characterised by good infiltration conditions especially in river valleys, where it comprises gravel formations [11]. The largest amount of water is found in the formations comprising the two lowest terraces, which are the major source of water for the water intake. In the study area, groundwater is found at relatively shallow depths (the mean thickness of the phreatic zone in the intake area does not exceed $4 \mathrm{~m}$ ) and there is no natural separating layer above the saturation zone [7]. The area is part of groundwater body No. 166 (following the division into 172 units). According to the No. 166 data sheet (EU identification: PLGW2000166), there are no areas at risk of nitrite pollution of agricultural origin and there is no risk of failing to meet the environmental goals of the Water Framework Directive (WFD) [12]. The main factors affecting the quality of water in the Dunajec river basin in the Beskid Sądecki Mountains are of natural origin: lithological structure, tectonic determinants, permeability of rock formations, and their size and porosity. Other important factors are anthropogenic. These include all negative effects of human activity on the soil and water, i.e., illegal disposal of waste and destabilisation of the water balance [13].

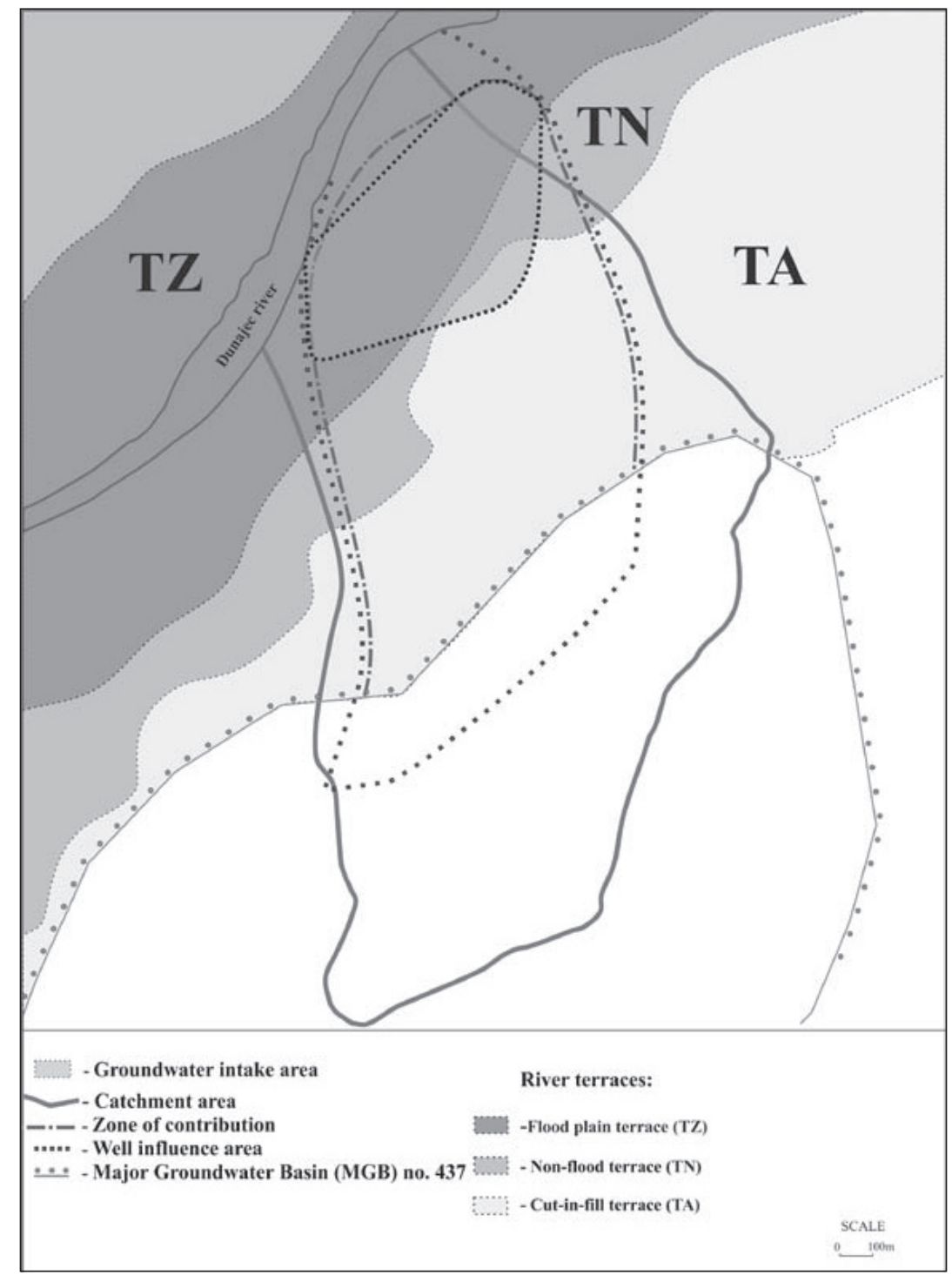

Fig. 4. Division of the study area into catchment areas [7, modified]. 
The present study is based on the results of geological tests performed to establish the available resources of the groundwater intake discussed. The works conducted included a hydrogeological survey (analysis of the development of the study area, literature review, field inventory). The geological works involved two phases of measurement pumping (lasting 96 hours each), one in natural conditions, the other in conditions of artificial water supply to the aquifer through basin units at the maximum possible well capacity, as well as measurement of the water table in the wells [7]. Model analysis of the obtained results confirmed the directions of groundwater flow toward the river valley, as presented in Fig. 2.

Based on different predicted times of vertical migration resulting from hydrodynamic properties of different formations, the study area was further divided into 3 catchment areas, equivalent to the three terraces of the river valley. They were delimited based on a detailed Geological Map of Poland, sheet No. 1035, Nowy Sącz. The three catchment areas were: the flood plain terrace (TZ) - with 15 wells comprising the intake, the non-flood terrace (TN) - with 1 well, and the cut-in-fill terrace (TA) located furthest away from the water intake (measured along the direction of water flow to the intake). The terraces are presented in Fig. 4.

The exposure of the aquifer to anthropogenic impact was evaluated for the delimited areas. There are several quantitative methods that can be used for that purpose (e.g., specifying the time of migration of potential pollutants from the terrain surface, measurement of thickness of layers forming the hydrodynamic barrier) or the so-called rank methods that assign rating values (ranks) to the parameters considered critical in vulnerability evaluation. Such methods include, e.g., the DRASTIC method [14], Foster's GOD method [15], the diversity method (recommended for fractured karst aquifers) or the EPIK method developed by Doerfliger et al. [16].

Due to the porosity of the hydrogeological medium, the size of the study area and the purpose of the analysis directed towards the properties on the natural environment rather than any specific type of pollutant, the evaluation of vulnerability to anthropogenic factors was performed using the following methods:

- Calculation of the vertical migration time of potential conservative pollutants through the vadose zone.

- Natural vulnerability of groundwater to pollution assessed using the DRASTIC index.

The time of vertical migration is a complex criterion, used for, e.g., determining the potential hazard to a major groundwater basin [17]. The evaluation of the protective properties of the vadose zone was performed using Bindeman's empirical method (formulas: (1) and (2). This method assumes an advection (convection) model of vertical transport of a conservative pollutant [18]. The choice of the formula application was preceded by a review of the publication of the test results comparing the formulas for the vertical seep time estimation. The results obtained by calculating the Bindeman formula with the formulas proposed by Witczak and Żurek and Macioszczyk were compared. The conclusions from the available publications have shown that the use of the Bindeman formula results in acquiring shorter times of vertical seepage through the aeration zone (especially for sand-gravel deposits of which the region of the analyzed intake is made), with identical susceptibility assessments in relation to other methods. Therefore, when deciding to use the Bindeman formula, the most adverse conditions affecting the threat to the analyzed groundwater were taken into account. In addition, the Bindeman formula is the most commonly used calculation methodology for documenting groundwater intake. This formula is recommended for rock centers of homogeneous character, to which undoubtedly belongs the region of the documented groundwater intake. Aluminium stratification is present in the profile are a small element of the aeration zone. The application of the Bindeman formula also allowed for obtaining comparable results with the results obtained for other intakes located in the Dunajec River basin.

The time of vertical migration depends in particular on the hydrogeological properties of the medium and the volume of infiltration water [18]:

$$
t_{a}=\frac{m_{a} \times n_{e}}{\sqrt[3]{I e^{2} \times k}}
$$

...where:

$t_{a}$ - time of vertical migration through the vadose zone [d]

$m_{a}$ - thickness of the vadose zone $[\mathrm{m}]$

$n_{e}-$ active (effective) porosity [-]

$k-$ hydraulic conductivity $[\mathrm{m} / \mathrm{d}]$

$I_{e}-$ ffective infiltration $[\mathrm{m} / \mathrm{d}]$

$$
I_{e}=P \times \omega[\mathrm{m} / \mathrm{d}]
$$

...where:

$P$ - precipitation $[\mathrm{m} / \mathrm{d}]$

$\omega-$ effective infiltration coefficient $[\mathrm{m} / \mathrm{d}]$

Data used in calculations:

- $m_{a}$ thickness of the vadose zone - for the area where the water intake is located, which corresponds to the flood plain terrace (TZ), the average depth to the water table based on profiles of the wells was used as the value of this parameter, i.e., $3.7 \mathrm{~m}$, while in the TN and TA terraces this value was based on correlation and was $5.0 \mathrm{~m}$ and $8.0 \mathrm{~m}$, respectively.

- $n_{e}$ active porosity - in TZ, where surface formations comprise mostly sandy soils, sands with gravel, sometimes with loam, the usual porosity is $0.2-0.5$, therefore a mean value of $0.35(35 \%)$ was used. In the case of TN and TA, this value was 0.45 . 
Table 1. Values of a scale of parameters of the DRASTIC index [14].

\begin{tabular}{|c|c|}
\hline $\begin{array}{c}\text { The DRASTIC evaluation } \\
\text { parameter }\end{array}$ & $\begin{array}{c}\text { The weight value for } \\
\text { dangerous investments }\end{array}$ \\
\hline D - Depth to groundwater table & 5 \\
\hline R - Net Recharge & 4 \\
\hline A - Aquifer media & 3 \\
\hline S - Soil media & 2 \\
\hline T - Topography & 1 \\
\hline I - Impact of the vadose zone & 5 \\
\hline C - Hydraulic Conductivity & 3 \\
\hline
\end{tabular}

(Source: [14])

- $k$ hydraulic conductivity - for TZ this was assumed to be $60 \mathrm{~m} / \mathrm{d}\left(6.94 \cdot 10^{-4} \mathrm{~m} / \mathrm{s}\right)$, for TA $-10 \mathrm{~m} / \mathrm{d}$ $\left(1.16 \cdot 10^{-4} \mathrm{~m} / \mathrm{s}\right)$, and for TN $-30 \mathrm{~m} / \mathrm{d}\left(3.47 \cdot 10^{-4} \mathrm{~m} / \mathrm{s}\right)$.

- $P$ precipitation was assumed to be $750 \mathrm{~mm} /$ year, which is the mean annual value for the region analysed.

- $\omega$ effective infiltration coefficient for TZ was assumed to be 0.2 , for $\mathrm{TN}-0.25$ and for $\mathrm{TA}-0.15$ [7].

The vulnerability evaluation was performed based on the DRASTIC rank method developed by the United States Environmental Protection Agency (US EPA 1987). The method involves the analysis of 7 environmental parameters determining the exposure level (acronym of their names form the name of the method) [14]:

D - Depth to groundwater table

$\mathrm{R}$ - net Recharge

A - Aquifer media

$\mathrm{S}$ - Soil media

T - Topography

I - Impact of the vadose zone

C - hydraulic Conductivity

The parameters analysed are assigned ratings $\mathrm{D}_{\mathrm{r}}$ within the range from 1 to 10 , the greater the vulnerability, the greater the value (i.e., conditions with the highest values are most conducive to pollution). The evaluation does not take into consideration the type and character of the potential pollutant [19].

In accordance with the DRASTIC method premises, apart from the assigned value of the $\mathrm{D}_{\mathrm{r}}$ rating, each parameter was assigned a weight specifying its importance in the migration process of potential pollutants [20]. According to the authors of the method, the greatest weight and therefore the greatest impact on vulnerability is assigned to the depth to the groundwater table and the character of formations comprising the vadose zone. These parameters affect the route that must be followed by pollutants and the effectiveness of the potential hydrodynamic barrier in the vertical migration route. Table 1 presents the weights assigned to parameters included in the analyses.

The DRASTIC index is the sum of products of ratings $\left(D_{r}\right)$ and weights $\left(D_{w}\right)$ assigned to the parameters listed in formulas (3) and (4):

$$
\begin{gathered}
\mathrm{IPZ}=D_{r} * D_{w}+R_{r} * R_{w}+A_{r} * A_{w}+ \\
S_{r} * S_{w}+T_{r} * T_{w}+I_{r} * I_{w}+C r * C_{w} \\
\mathrm{IPZ}=\sum_{p=1}^{7}(w * r)_{p}=\sum_{p=1}^{7} w_{p} * r_{p}
\end{gathered}
$$

...where:

$r$ - assumed value of the parameter rating

$w$ - weight of the parameter specified in the method

$p$ - parameter number

The calculated values of the DRASTIC index allow for determining categories of groundwater based on its vulnerability to pollution (Table 2).

\section{Results and Discussion}

As a result of the calculations performed, the time of vertical migration through the vadose zone was established (Table 3). Additionally, calculations were performed for TZ, whereby limit values of porosity and hydraulic conductivity obtained during hydrogeological field studies were used to determine conditions most conducive to groundwater protection $\left(\mathrm{T}_{\max }\right.$ protection $)$ and conditions with increased hazard vulnerability $\left(\mathrm{T}_{\text {min. protection }}\right)$, respectively [7].

The obtained mean vertical migration times ranged from 60 days in the case of TZ to over 366 days for TA. The estimated infiltration time for $\mathrm{TZ}$ in extreme conditions ranged from 23 days for parameters most conducive to pollution ( $\mathrm{T}_{\text {min. protection }}$ ) to over 155 days for parameters most conducive to protection $\left(\mathrm{T}_{\text {max. protection }}\right)$. There is almost a seven-fold difference between these limit values, which reflects complex hydrogeological conditions in the study area. Based on the results obtained, we found that the calculated vertical migration time is close to the 30 -day migration time considered bacteriologically safe for groundwater intakes. The duration of this period is related to natural

Table 2. Categories of groundwater based on its vulnerability to pollution [14].

\begin{tabular}{|c|c|c|c|c|}
\hline \multicolumn{1}{|c|}{ DRASTIC index } & $<100$ & $101-140$ & $141-200$ & $>200$ \\
\hline The vulnerability of groundwater to pollution & low & medium & high & very high \\
\hline (Source: $[14]$ )
\end{tabular}


Table 3. Calculating the time of vertical migration through the vadose zone [7].

\begin{tabular}{|c|c|c|c|c|c|}
\hline Parameter & $\mathrm{TZ}$ & $\mathrm{TN}$ & $\mathrm{TA}$ & $\mathrm{TZ}_{\text {min. protection }}$ & $\mathrm{TZ}_{\text {max. protection }}$ \\
\hline Thickness $\mathrm{m}_{\mathrm{a}}[\mathrm{m}]$ & 3,7 & 5 & 8 & 3,7 & 3,7 \\
\hline Porosity $\mathrm{n}_{\mathrm{e}}[-]$ & 0,35 & 0,45 & 0,45 & 0,2 & 0,5 \\
\hline The amount of precipitation $\mathrm{P}[\mathrm{m} / \mathrm{year}]$ & 0,75 & 0,75 & 0,75 & 0,75 & 0,75 \\
\hline Infiltration rate $\omega[-]$ & 0,2 & 0,25 & 0,15 & 0,2 & 0,2 \\
\hline Effective infiltration $\mathrm{I}_{\mathrm{e}}[\mathrm{m} / \mathrm{d}]$ & $4,11 \cdot 10^{-4}$ & $5,14 \cdot 10^{-4}$ & $3,08 \cdot 10^{-4}$ & $4,11 \cdot 10^{-4}$ & $4,11 \cdot 10^{-4}$ \\
\hline Hydraulic Conductivity $\mathrm{k}[\mathrm{m} / \mathrm{d}]$ & 60 & 30 & 10 & 186 & 10 \\
\hline The time of percolation $\mathrm{t}_{\mathrm{a}}[\mathrm{d}]$ & 59,84 & 112,89 & 366,21 & 23,45 & 155,35 \\
\hline
\end{tabular}

(Source: [7])

Table 4. Evaluation of the DRASTIC index [7, modified].

\begin{tabular}{|c|c|c|c|c|c|c|}
\hline Parameter & Weight $*$ & $\mathrm{TZ}$ & $\mathrm{TN}$ & $\mathrm{TA}$ & $\mathrm{TZ}_{\text {min. protection }}$ & $\mathrm{TZ}_{\text {max. protection }}$ \\
\hline D - Depth to groundwater table & 5 & 9 & 7 & 7 & 9 & 9 \\
\hline R - Net Recharge & 4 & 6 & 8 & 6 & 8 & 6 \\
\hline A - Aquifer media & 3 & 8 & 5 & 4 & 9 & 4 \\
\hline S - Soil media & 2 & 9 & 9 & 9 & 9 & 9 \\
\hline T - Topography & 1 & 9 & 5 & 3 & 9 & 5 \\
\hline I - Impact of the vadose zone & 5 & 8 & 6 & 4 & 8 & 4 \\
\hline C - Hydraulic Conductivity & 3 & 8 & 6 & 2 & 10 & 2 \\
\hline DRASTIC indeks & & 184 & 153 & 118 & 201 & 130 \\
\hline
\end{tabular}

*by [14] (Source: [7], changed)

biodegradation of such pollutants. However, it is important to note that most frequently such pollutants originate from illegal dumping of wastewater directly to the water-soil environment. In such cases, the time needed for bacteria to reach the groundwater table is considerably shorter and the exposure level is increased [7]. The analyses conducted confirmed that vertical infiltration requires a short time.

Next, the rating values for individual parameters were evaluated and the DRASTIC index was calculated using the algorithm presented above. The analyses performed demonstrated medium vulnerability in the case of TA and high vulnerability in the case of TN and TZ. Similar to the vertical migration time calculation, extreme conditions were evaluated for TZ. In the case of conditions least conducive to groundwater protection, the pollution vulnerability value was very high, while in the case of environmental conditions most conducive to ground water protection, the obtained value was medium. Table 4 presents the results of the DRASTIC evaluation.

The results of parameter indexation obtained were used to develop a map representing spatial distribution of groundwater pollution vulnerability (Fig. 5). Zones of various levels of potential hazard vulnerability were delineated: TZ with high vulnerability (very high in extreme conditions), TN with high vulnerability and TA with medium vulnerability. The medium vulnerability of the cut-in-fill terrace suggests that pollutants have a certain impact on groundwater protection along the direction of the inflow of the water to the intake.

The study results confirmed a low protection capability of the aquifer analysed, which mainly stems from the low depth to the groundwater table and the lack of a natural hydrodynamic barrier. When compared, the two methods yielded similar results. Areas with a short infiltration time were the same as those with a high DRASTIC index value, i.e., those whose vulnerability was identified as high.

Correlation of the obtained results confirmed the suitability of the DRASTIC rank method for the evaluation of porous mediums with linear groundwater flow such as the Major Groundwater Basin No. 437 Dunajec River Valley analysed in the study. In media of this type, the main source of water supply is precipitation. Therefore, the formations comprising the vadose zone and the depth to the groundwater table have a considerable impact on vulnerability. 


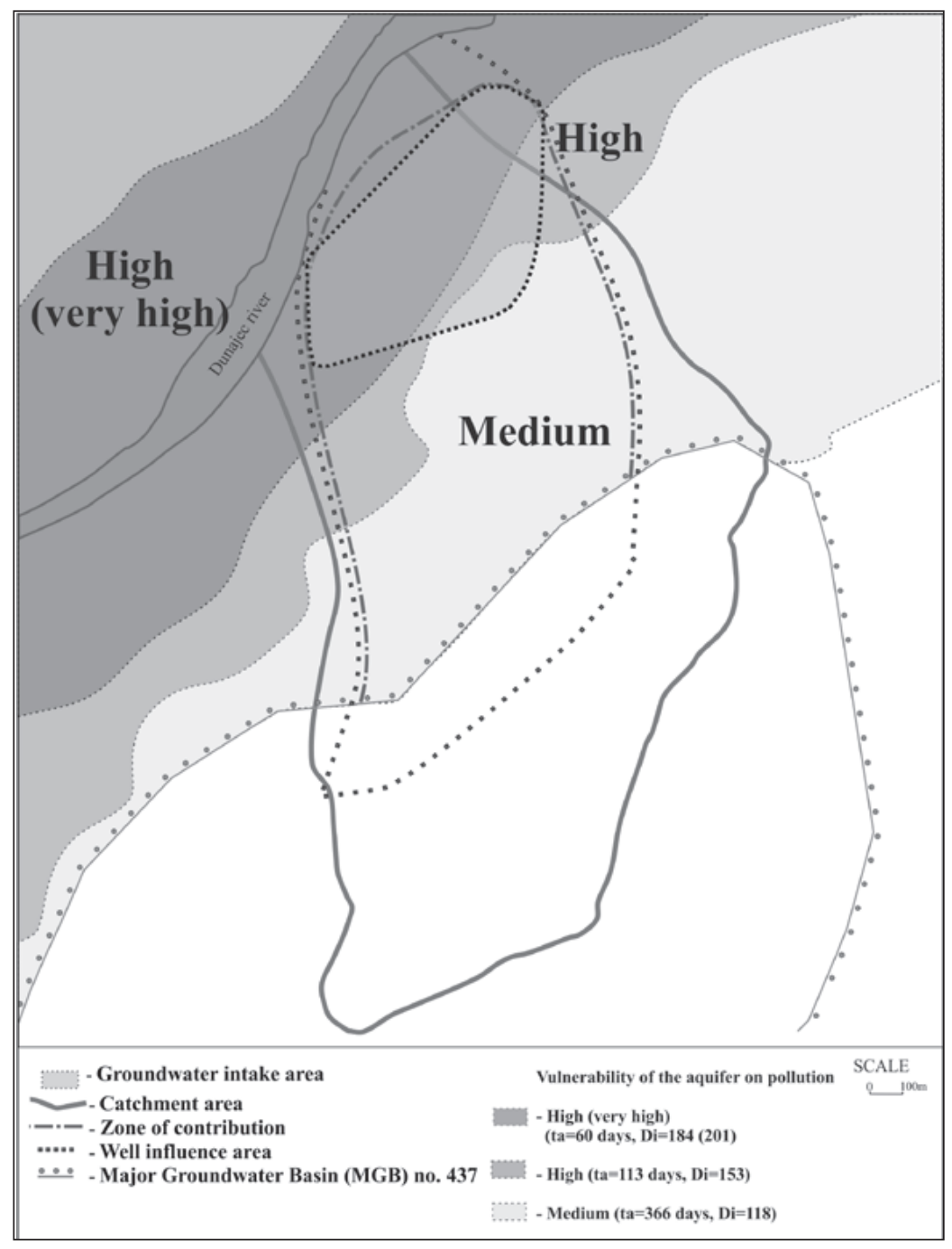

Fig. 5. Map of the susceptibility to polluting the water-bearing level [7, changed].

Results obtained in the analyses were compared with the current state of knowledge presented in Polish and international literature. The assessment of susceptibility of the water-soil environment based on the DRASTIC method is widely used, in particular in connection with GIS systems. Research using the indicated techniques was carried out, among others by Abdeslam et al. [21], for the assessment of groundwater environment exposure in the semi-arid regions of Mistas, Boukhadra and El-Aouinet. As a result of the assessment, a map of groundwater sensitivity was built. Testing the sensitivity of the aquifer using the DRASTIC model in the geographic information system (GIS) environment was also carried out by Colins and team [22] for the Kodaganar River basin (India) and Oluwapelumi O. Ojuri et al. [23] based on a case study for the Lagos region (Nigeria). The assessment of the sensitivity of groundwater in the Lagos area has shown that the DRASTIC model can be used to plan groundwater monitoring networks, especially for sensitive areas. The authors drew attention to the accuracy of the obtained results of the DRASTIC assessment depending on the availability and accuracy of hydrogeological data from wells supplying drinking water. The assessment of the impact of the landfill exploitation (India) to groundwater based on the GIS spatial information system and the DRASTIC weighting method was conducted by Jaseela et al. [24]. During the analysis, the sensitivity of the aquifer was assessed, which was then verified by the results of chemical and bacteriological tests of the collected samples. The obtained results confirmed the correlation of high concentrations of dissolved substances and E. coli bacteria for zones with high susceptibility to pollution. Research carried out by Hosseini and Saremi [25], showed that results using the DRASTIC method are more accurate compared to the susceptibility assessment based on the GOD method.

\section{Conclusions}

The analyses conducted yielded the following conclusions: 
1) Spatial variability of groundwater vulnerability to migration of pollutants from ground surface conforms to what was predicted.

2) Vulnerability of groundwater to pollution is greater the closer the studied area of the river basin is to the river valley. These values result directly from the features of geological and geomorphological structure of the terrain.

3) The quantity of highly permeable formations (river outwash) increases in the phreatic zone, which negatively affects the class of groundwater vulnerability to stress factors.

4) There exist mutual relations between the hydrogeological medium parameters analysed - time of vertical migration through the vadose zone and vulnerability to pollution.

5) In areas characterised by short vertical migration times, high potential hazard values were obtained.

6) The length of the vertical transport route (depth to the groundwater table) and the lithological characteristics of the formations in the vadose zone are the most important factors in the migration of potential stress factors.

7) There exists a correlation between the applied methods of vulnerability evaluation in a porous hydrogeological medium - the calculation of vertical infiltration time and the DRASTIC index.

The results of the analyses may be used in planning works aimed toward minimizing risk, especially for the purpose of water resources protection. Appropriate spatial planning supported by environmental analyses is the basis for correct and responsible management of water resources. Vulnerability evaluation may be useful in decision-making procedures when preparing an environmental impact assessment or while selecting locations for potential investment projects. This is particularly important in the case of areas with a high vulnerability level that require detailed environmental and health risk analyses. Regions with high vulnerability to anthropogenic impact should receive priority attention when considering protection of groundwater resources.

One of the benefits related to the use of the methods discussed is that the obtained results can be easily processed. However, when using these methods, it is important to take into consideration the characteristics of any given area, available sources of data and the prevailing hydrodynamic conditions. Changes in spatial distribution of the parameters related to a given medium often necessitate zoning of the study area.

It is important to note that the natural (intrinsic) vulnerability of groundwater is the reflection of natural properties of the water-bearing system. In order to evaluate its vulnerability to a specific type of anthropogenic impact (sources of pollution), it is recommended to perform a specific vulnerability evaluation that will take into consideration the behaviour and transformation of the polluting agent on its migration route.
The authors would like to highlight the importance of performing a thorough hydrogeological investigation of the area whose vulnerability is being verified. Without adequate analyses of natural environmental conditions it is impossible to obtain reliable results of vulnerability level evaluation. The stage of preparation and collecting hydrogeological data is the most timeconsuming and expensive part of the evaluation.

\section{Acknowledgements}

This research was financially support by the Polish Ministry of Science and Higher Education (grant No. 0033/DW/2018/02) and by AGH-UST (grant No. 16.16.140.315).

\section{Conflict of Interest}

The authors declare no conflict of interest.

\section{References}

1. KICIŃSKA A. Chemical and mineral composition of fly ashes from home furnaces, and health and environmental risk related to their presence in the environment. Chemosphere, 215, 574, doi: https://doi.org/10.1016/j. chemosphere.2018.10.061, 2019.

2. KICIŃSKA A., BOŻĘCKI P. Metals and mineral phases of dusts collected in different urban parks of Krakow and their impact on the health of city residents. Environmental Geochemistry and Health, 40, 473, doi:10.1007/s10653-0179934-5, 2018.

3. PANASIEWICZ A. Environmental risk management as a tool to support a more environmentally friendly economy. Scientific work of the University of Economics in Wroclaw, 318, 255, 2013 [In Polish].

4. KICIŃSKA A. Risk assessment of children's exposure to potentially harmful elements (PHE) in selected urban parks of the Silesian agglomeration. E3S Web of Conferences: 10 UNSP 00035, doi: 10.1051/e3sconf/20161000035, 2016.

5. DOWGIAŁŁO J., KLECZKOWSKI A.S., MACIOSZCZYK T., RÓŻKOWSKI A., [ed.], SZCZEPAŃSKI A., WITCZAK S., ROGÓŻ M., SADURSKI A., RÓŻKOWSKI A., KRAJEWSKI S., MACIOSZCZYK A., MACIOSZCZYK T., MAŁECKA D., BOCHEŃSKA T. Hydrogeological dictionary. Polish Geological Institute, Warszawa, Poland, pp. 150, 2002 [In Polish].

6. KICIŃSKA A. Assessment of the road traffic impact on accumulation of selected elements in soils developed on Krynica and Bystrica subunit (Magura Nappe, Polish Outer Carpathians). Carpathian Journal of Earth and Environmental Sciences, 11 (1), 245, 2016.

7. NIKIEL G., HERMAŃSKA-NIKIEL D., WYSOWSKA E., STOBIECKI Z. Hydrogeological documentation establishing exploitation resources of a multi-hole groundwater intake in Stary Sącz. Archive of Sądeckie Wodociaggi, Poland, 2015 [In Polish].

8. WIEWIÓRSKA I., KULIG M. Optimization of the infiltration pool irrigation system in the Water Treatment 
Plant - Stary Sącz. Gas, Water and Sanitary Technology, 04/91, 196, 2017 [In Polish].

9. PACZYŃSKI B., SADURSKI A. [ed.], BURZYŃSKI K., PRUSZKOWSKA M., CHMURA A., PACHOLEWSKI A., WAGNER J., CHOWANIEC J., CIĘŻKOWSKI W., DĄBROWSKI S., DOWGIAŁŁO J., GÓRSKI J., PRZYBYŁEK J., HERBICH P., KAZIMIERSKI B., MITRĘGA J., NOWICKI Z., PACZYŃSKI B., SADURSKI A., SKRZYPCZAK L., WOŹNIKCKA M., HOC R., JEZIERSKI P., WIŚNIOWSKI Z., KACHNIC J., KACHNIC M., POMIANOWSKA H., KLECZKOWSKI A.S., KNYSZYŃSKI F., KRAJEWSKI S., MAŁECKA D., MAŁECKI J.J., KOWALCZYK A., RÓŻNOWSKI J., RUBIN H., RUBIN K., KOZERSKI B., KRECZKO M., LIDZBARSKI M., PRUSSAK E., MICHNIEWICZ M., MOTYKA J., NOWAKOWSKI C., PRAŻAK J., STAŚKO S., ZUBER A. Regional hydrogeology of Poland. Vol. 1 - Sweet waters, Polish Geological Institute, Warszawa, Poland, 108, 2007 [In Polish].

10. NIKIEL G., HERMAŃSKA-NIKIEL D., WYSOWSKA E., A water-based survey on special use of water in the field of artificial groundwater supply from a multi-hole intake in Stary Sacz and the implementation of water facilities for this purpose. Archive of Sądeckie Wodociągi, Poland, 2015 [In Polish].

11. MIKOŁAJKÓW J., SADURSKI A. [ed.], CHOWANIEC J., CZEBRESZUK J., FILAR S., GUZIK M., HERBICH P., HOC R., HONCZARUK M., JÓŹWIAK K., KARWIK A., KRAWCZYK J., LIDZBARSKI M., ŁUSIAK R., MIKOŁAJKÓW J., NIDENTAL M., OLESIUK G., PASIEROWSKA B., PIASECKA A., PRAŻAK J., PRZYTUŁA E., RAZOWSKA-JAWORAK L., SADURSKI A., SERAFIN R., SKRZYPCZYK L., STAROŚCIAK A., SZELEWICKA A., SZYDLO M., ŚLIWIŃSKI Ł., TARNAWSKA E., WARUMZER R., WĘGLARZ D., WIŚNIOWSKI Z., WITCZAK S. Guidebook of Main Underground Water Reservoirs in Poland, PIG PIB, Warszawa, Poland, 327, 2017 [In Polish].

12. http://www.pgi.gov.pl/psh/zadania-psh (accessed on 18 May 2019)

13. KICIŃSKA A. Conditions of surface water quality in Beskid Sądecki. AGH, Kraków, Poland, 107, 2010 [In Polish].

14. ALLER L., BENNETT T. LEHR J.H., PETTY R. J., HACKETT G. DRASTIC - A Standardized System for Evaluating Ground Water Pollution Potential Using Hydrogeologic Setting. United States of Environmental Protection Agency, Ada, Oklahoma, USA, 600/2-87/0035, 17, 1987.

15. FOSTER S.S.D. Fundamental Concepts in aquifer vulnerability, pollution risk and protection strategy [In:] Vulnerability of soil and groundwater to pollutants proceedings of the International Conference on March 30-April 3, 1987 at Noordwijk aan Zee, The Netherlands organized by National Institute of Public Health and Environmental Hygiene, W. VAN DUIJVENBOODEN
AND H.G. VAN WAEGENINGH [ed.], The Hague, Proceedings and Information/TNO Committee on Hydrological Research, 38, 69, 1987.

16. DOERFLIGER N., JEANNIN P.Y., ZWAHLEN F. Water vulnerability assesment in karst environment: a new method of defining protection areas usingg a multi-atribute approach and GIS tools (EPIK method). Environmental Geology, 39 (2), 165, 1999.

17. ŻUREK A., ROŻNOWSKI J. Threat to the quality of groundwater in selected protected areas within the range of Upper Jurassic reservoir in the region of Krakow [In:] Water in protected areas, PARTYKA J., POCIASKKARTECZKA J. [ed.], Kraków, Poland, 273, 2008 [In Polish].

18. KLECZKOWSKI A.S. [ed.] Groundwater protection. Geological Publishers, Warszawa, Poland, 1984, as cited in DUDA R., WITCZAK S., ŻUREK A.J.A. Map of Poland's groundwater sensitivity to pollution 1: 500,000. Methodology and text explanations. AGH, Kraków, Poland, 15, 2011 [In Polish].

19. GRAF R. The assessment of vulnerability of shallow groundwater to pollution as the basis for conservation measures in the catchment [In:] Valorisation of the natural environment in spatial planning, KISTOWSKI M., KORWEL-LEJKOWSKA B. [ed.] Gdańsk-Warszawa, 19, 298, 2007 [In Polish].

20. DUDA R., WITCZAK S., ŻUREK A.J.A. Map of Poland's groundwater sensitivity to pollution 1: 500,000. Methodology and text explanations. AGH, Kraków, Poland, 15, 2011 [In Polish].

21. ABDESLAM I., FEHDI C., DJABRI L. Application of drastic method for determining the vulnerability of an alluvial aquifer: Morsott - El Aouinet north east of Algeria: using arcgis environment. International Conference on Technologies and Materials for Renewable Energy, Environment and Sustainability, TMREES17, 21-24 April 2017, Beirut Lebanon. Energy Procedia, 119, 308, 2017.

22. COLINS J., SASHIKKUMAR M.C., ANAS P.A., KIRUBAKARAN M. GIS-based assessment of aquifer vulnerability using DRASTIC Model: A case study on Kodaganar basin. Earth Sciences Research Journal, 20 (1), 2016.

23. OLUWAPELUMI O. OJURI, OLUFUNMILOLA T. BANKOLE Groundwater Vulnerability Assessment and Validation for a Fast Growing City in Africa: A Case Study of Lagos, Nigeria. Journal of Environmental Protection, 4, 454, 2013

24. JASEELA C., PRABHAKAR K., HARIKUMAR P.S.P. Application of GIS and DRASTIC Modeling for Evaluation of Groundwater Vulnerability near a Solid Waste Disposal Site. International Journal of Geosciences, 7, 558, 2016.

25. HOSSEINI M., SAREMI A. Assessment and Estimating Groundwater Vulnerability to Pollution Using a Modified DRASTIC and GODS Models (Case Study: Malayer Plain of Iran). Civil Engineering Journal, 4 (2), 2018. 